\title{
Bioactive constituents of three algal species extracts and their anticancer activity against human cancer cell lines
}

\author{
Olfat M.A. Salem ${ }^{1}$, Reham K. El Assi ${ }^{1}$, Saleh M.A ${ }^{2}$ \\ ${ }^{1}$ Botany and Microbiology Department, Faculty of Science, Helwan University, \\ Cairo, Egypt \\ ${ }^{2}$ Chemistry Department, Faculty of Science, Helwan University, Cairo, Egypt
}

\begin{abstract}
:
This study was designed to identify the bioactive constituents of the red alga Gracilaria dendroides and one green alga Chlorella vulgaris and Microcystis sp. (cyanobacteria) by GC /Mass and HPLC analysis and assay the cytotoxic activity of the methanolic extract from the three species against three types of human cancer cell lines (liver HEPG-2, colon and breast MCV-7). The research was performed as an in vitro study. The effect of extract on proliferation of cell lines was measured by Methyl thiazolyl tetra zolium (MTT) colorimetric method. The results showed that the compounds identified by GC-MS were 19 compounds in G. dendroides, 11 compounds in Chlorella and 12 compounds in Microcystis,. The most abundant compounds were fatty acids, methyl esters and terpenoids. HPLC analysis identified 4 compounds in Gracilaria and 6 compounds in Chlorella and Microcystis. Crude extract of Gracilaria had the strongest activity on HepG-2 cell lines with $\mathrm{IC}_{50}$ value $15.46 \mu \mathrm{g} / \mathrm{ml}$. Concerning MCF-7 cell lines, the most potent crude extract was the Chlorella vulgaris $\left(\mathrm{IC}_{50}\right.$ value of $\left.15.53 \mu \mathrm{g} / \mathrm{ml}\right)$. On the other hand, evaluation the cytotoxic activity for the three algae species extracts against epithelial colorectal adenocarcinoma cells (CaCO-2) showed higher activity for Chlorella vulgaris with $\mathrm{IC}_{50}=14.63 \mu \mathrm{g} / \mathrm{ml}$. Accordingly, we can say that Chlorella had the strongest activity on MCF-7 and (CaCO-2) cell lines while HepG-2 cell lines most affected by Gracilaria extract.
\end{abstract}

Keywords: Anticancer, Bioactive compounds, Gracilaria, Chlorella, Microcystis

\section{Introduction}

Most of the anticancer drugs currently used in chemotherapy (the standard treatment method) are cytotoxic to normal cells and cause immune toxicity so scientists are interested in working on plants, marine organism and 
microorganisms natural compounds for the discovery and identification of new antitumor drug with low side effects (Xu et al., 2009). Marine algae contain various biologically active compounds which have been used as source of food, feed and medicine. Until now, more than 2400 marine natural products have been isolated from seaweeds (Manilal $\boldsymbol{e t}$ al., 2009). The crude extract of red alga Gracilaria corticata had significant anticancer activity and it might be a good candidate for further investigations in order to develop a natural compound as an anticancer agent which can be used for the production of potential anticancer drug and novel pharmaceutical leads. The polysaccharides and peptides isolated from seaweeds have become a matter of great interest for cancer therapy. The mechanisms of their anticancer activity are related to their ability to suppress the growth of cancer cells (cytotoxic or cytostatic effects), to enhance the immune responses and to inhibit tumor angiogenesis (Itoh et al., 1993; Apryshko et al., 2005; Matsubara et al., 2005). The anticancer potential of the polysaccharides extracted from 7 marine algae by using the cells of breast cancer (MCF7) and colon cancer ( $\mathrm{CoCa} 2)$ evaluated as mentioned by Ghada et al. (2018). Microalgae synthesize compounds with known in vitro and in vivo biological activity against different tumor cell lines. The bioactive compounds which have the ability to inhibit cancer cell proliferation by activating apoptotic pathways can be employed as potential chemotherapeutic drugs. Cyanobacteria produce biologically active and chemically diverse compounds belonging to cyclic peptides, lipopeptides, fatty acid amides, alkaloids and saccharides. More than $50 \%$ of the marine cyanobacteria are potentially exploitable for extracting bioactive substances which are effective in killing cancer cells by inducing apoptotic death (Ahmed $\boldsymbol{e t}$ al., 2017). Microcystins are a group of chemically related cyclic peptides and most commonly studied group of cyanotoxins (Kehr $\boldsymbol{e t}$ al., 2011). The anticancer activity of Chlorella vulgaris against breast cancer cell lines was determined by means of MTT assay (a colorimetric assay) to determine cell viability by assessing the values of IC50 and the results showed that the MCF7 was the cancer cell lines that reach $50 \%$ of inhibition by algae (Mohd $\boldsymbol{e t}$ al., 2012). Zhang et al. (2017) showed that Chlorella vulgaris induces apoptosis of human non-small cell lung carcinoma. Recently the importance of strain selection taken into consideration as activity varied between strains of the same species as mentioned by Ordog et al. (2004). Michael et al. (2014) showed that fatty acid derivatives often exhibit activity against cancer cells, but not 
normal cells. This appears to be a property that augers well for new anti-cancer drug development based on lipids. The available information does not provide a full understanding for this selectivity because the targeted pathways may be present in both cell types. The discovery and identification of new anti-tumor drugs with low side-effects on immune system has become an essential goal in immune pharmacology (Xu et al., 2009). Regarding the reduced side-effects of plants and algae compounds, scientists are interested in working on them to find new formulations. In the present study therefore, Gracilaria dendroides Chlorella vulgaris and Microcystis sp extracts were examined in vitro to assay the cytotoxic activity on proliferation of human cancer cell lines HEPG-2, colon and breast MCV-7.

\section{Materials and Methods}

\section{Biological materials}

\section{Gracilaria dendroides}

Gracilaria was manually collected from Mediterranean Coast at Baltim

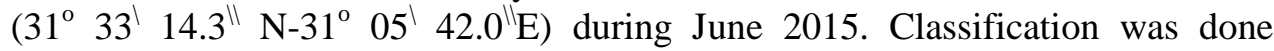
according to Aleem (1993). The alga (were collected in a considerable amount for assay in plastic bags and transferred to the laboratory. At the laboratory; the algal material was sorted to the species level, cleaned from epiphytes and were successively rinsed with sea water, fresh water and distilled water. After this operation it was air dried, weighed to the nearest gram and powdered using electric mill in preparation for the extractions.

\section{Microalgae and cyanobacteria growth conditions}

Chlorella vulgaris and Microcystis sp. were isolated from Nile River and purified. It was identified morphologically by light microscopy according to Prescott, 1982, and the growth conditions optimization were examined; the two organisms were cultivated in BG11 medium (Rippka et al., 1979). For the production of biomass, exponentially growing algae culture was transferred into 
fresh sterile medium [10\% (v/v) of inoculums]. Cultures were illuminated by tubular fluorescent lamps with light intensity of $25 \mu \mathrm{mol}$ photons $\mathrm{m}^{-2} \mathrm{~s}^{-1}$. Examination of the species growth optimization takes place as follow; $\mathrm{pH}$ intervals from 4,5,6,7,8,9 to identify the optimum initial $\mathrm{pH}$, photoperiod (light/ dark) intervals (continuous light, $12 \mathrm{~h}: 12 \mathrm{~h}, 16: 8$ ), the different growth temperatures $\left(15,20,25,30,35 \mathrm{C}^{\circ}\right)$. The optimum incubation period was examined by measuring the organism growth every 3 days for 30 days. All experiments mentioned above were performed in triplicates using $1 \mathrm{~L}$ Erlenmeyer flasks. The growth of the organism was determined by dry weight and chlorophyll-a determination.

\section{Preparation of Algal Extract}

One hundred grams of dried Gracilaria dendroides powder were suspended in $200 \mathrm{~mL}$ aqueous methanol $70 \%$ for $72 \mathrm{~h}$ then centrifuged at 5000 rpm for 10 minutes (Élica et al, 2013). To identify bioactive compounds of algal extracts GC-MS and HPLC analysis were takes place. The mass from these extracts was measured and stored under refrigeration for subsequent cytotoxicity assays

\section{Microalgae and cyanobacteria}

One hundred milligram of dried algal cells harvested at stationary phase (after 21 days) were grinded by $70 \%$ methanol then centrifuged at $5000 \mathrm{rpm}$ for 10 minute and the extract using for GC-MS and HPLC analysis to identify the bioactive compounds.

\section{GCIMS Analysis and active compound identification:-}

GC/MS system (Agilent Technologies) was equipped with gas chromatograph (7890B) and mass spectrometer detector (5977A) at Central Laboratories Network, National Research Centre, Cairo, Egypt. The GC was equipped with HP-5MS column (30 m x $0.25 \mathrm{~mm}$ internal diameter and $0.25 \mu \mathrm{m}$ film thickness). Analyses were carried out using helium as the carrier gas at a flow rate of $1.0 \mathrm{ml} / \mathrm{min}$ at a split ratio of $20: 1$, injection volume of $1 \mu 1$ and the following temperature program: $50{ }^{\circ} \mathrm{C}$ for $1 \mathrm{~min}$; rising at $20{ }^{\circ} \mathrm{C} / \mathrm{min}$ to $200{ }^{\circ} \mathrm{C}$ Egyptian J. of Phycol. Vol. 21, 2020 
and held for $5 \mathrm{~min}$; rising at $3{ }^{\circ} \mathrm{C} / \mathrm{min}$ to $230{ }^{\circ} \mathrm{C}$ and held for $15 \mathrm{~min}$. The injector and detector were held at $250{ }^{\circ} \mathrm{C}$. Mass spectra were obtained by electron ionization at $70 \mathrm{eV}$ and using a spectral range of m/z 20-550 and solvent delay 1.8 min. Identification of different constituents was determined by comparing the spectrum fragmentation pattern with those stored in Wiley and NIST Mass Spectral Library data.

\section{HPLC Analysis of algal extract:-}

The sample $(100 \mu \mathrm{g} / \mathrm{mL})$ solution was prepared using high performance liquid chromatography (HPLC) analytical grade solvent of $\mathrm{MeOH}$, filtered using a membrane disc filter $(0.2 \mu \mathrm{m})$ then subjected to LC-ESI-MS analysis. Samples injection volumes $(10 \mu \mathrm{L})$ were injected into the UPLC instrument equipped with $\mathrm{m}$ reverse phase C-18 column (ACQUITY UPLC - BEH C18 $1.7 \mu \mathrm{m}$ particle size $-2.1 \times 50 \mathrm{~mm}$ Column). Sample mobile phase was prepared by filtering using $0.2 \mu \mathrm{m}$ filter membrane disc and degassed by sonication before injection.

Mobile phase elution was made with the flow rate of $0.2 \mathrm{~mL} / \mathrm{min}$ using gradient mobile phase comprising two eluents: $\mathrm{A}$ is $\mathrm{H}_{2} \mathrm{O}$ acidified with $0.1 \%$ formic acid and $\mathrm{B}$ is $\mathrm{MeOH}$ acidified with $0.1 \%$ formic acid. Elution was performed using the above gradient. The parameters for analysis were carried out using negative ion mode as follows: source temperature $150{ }^{\circ} \mathrm{C}$, cone voltage 30 $\mathrm{eV}$, capillary voltage $3 \mathrm{kV}$, desolvation temperature $440{ }^{\circ} \mathrm{C}$, cone gas flow $50 \mathrm{~L} / \mathrm{h}$, and desolvation gas flow $900 \mathrm{~L} / \mathrm{h}$. Mass spectra were detected in the ESI between $\mathrm{m} / \mathrm{z}$ 100-1000. The peaks and spectra were processed using the Maslynx 4.1 software and tentatively identified by comparing its retention time (Rt) and mass spectrum with reported data.

\section{Cytotoxic activity of algal extract in vitro}

To determine the cytotoxicity of algal extract against studied cancer cell lines; $1 \mathrm{mg}$ of algal extract dissolved in $0.1 \mathrm{~mL}$ DMSO , and this extract tested against three types of human cancer cells (liver, colon and breast) by using Methyl thiazolyl tetrazolium (MTT assay) which used as a quantitative and approved method at VACSERA center. In this method, $10 \mu \mathrm{l}$ of MTT stock solution (5 $\mathrm{mg} / \mathrm{ml}$ in phosphate buffer solution) was added to $90 \mu \mathrm{l}$ medium of wells 
which were treated by different concentrations of algal extract for $72 \mathrm{hrs}$. The micro plate was incubated at $37^{\circ} \mathrm{C}$ for $4 \mathrm{hrs}$ and then, the optical density of each well was read by microplate reader (ASYS - EXPERT 96) at $540 \mathrm{~nm}$ (Van de Loosdrecht et al., 1994).

\section{Results and Discussion}

Growth optimization of the two species showed that the optimum initial $\mathrm{pH}$ of the BG11 medium was 7, the optimum (light/ dark) cycle was 16hrs: 8hrs at $27 \pm 2^{\circ} \mathrm{C}$ for the two species. The optimum incubation period was 21 days for Microcystis sp. and 27 days for Chlorella vulgaris.

\section{GCIMS analysis}

\section{GCWMS analysis of Gracilaria dendroides:-}

Methanol crude extract of Gracilaria resulted in the identification of different compounds which were predominated in Table 1 . The spectrum analysis revealed the presence of 19 compounds; 9-octadeconic acid methylester with peak area of $38.97 \%$ followed by 9,12 -octadecadionic acid(z,z) methylester with $8.41 \%$ and Squalene $8.40 \%$.

In our results fatty acids and methyl esters were represented the dominant compounds as mentioned by Venkataraghavan et al. (2019) showed that the analysis of Gracilaria corticata methanol extract revealed several bioactive compounds such as: fatty acids, free saturated fatty acids and methyl esters.

\section{GCIMS analysis of Chlorella vulgaris:-}

The spectrum analysis of Chlorella extract revealed the presence of 11 compounds, the most abundant compounds being 9-Octadeconic acid, Zmethyl ester $(27.84 \%)$ represented the highest percentage in the extract followed by Exobornylacetate with $21.63 \%$ and pinocarvon $9.83 \%$ (Table 2). 
Table 1: GCIMS of methanol extract of Gracilaria dendroides

\begin{tabular}{|c|c|c|c|c|c|c|c|}
\hline No & Name of compound & $\begin{array}{l}\text { Common } \\
\text { name }\end{array}$ & Group & $\begin{array}{l}\text { Molecular } \\
\text { formula }\end{array}$ & $\begin{array}{c}\text { Molecular } \\
\text { weight }\end{array}$ & $\begin{array}{c}\text { Peak } \\
\text { area\% }\end{array}$ & RT \\
\hline 1 & Dodecane (CAS) & & Alkane & $\mathrm{C} 12 \mathrm{H} 26$ & 170 & 0.93 & 10.41 \\
\hline 2 & Eicosane & & Alkane & $\mathrm{C} 2 \mathrm{OH} 42$ & 282 & 1.83 & 16.77 \\
\hline 3 & $\begin{array}{l}\text { Isoborneol, trifluroacetate } \\
\text { ester }\end{array}$ & & Ester & $\mathrm{C} 12 \mathrm{H} 17 \mathrm{~F} 3 \mathrm{O} 2$ & 250 & 0.63 & 17.03 \\
\hline 4 & 1,2,3-propentriol,triacetat & $\begin{array}{l}\text { Glyceryl } \\
\text { triacetate }\end{array}$ & Fatty acid & C9H14O6 & 218 & 1.00 & 18.81 \\
\hline 5 & $\begin{array}{l}\text { 3- } \\
\text { Trifluoroacetoxytetradecane }\end{array}$ & & & $\mathrm{C} 16 \mathrm{H} 29 \mathrm{~F} 3 \mathrm{O} 2$ & 310 & 1.59 & 19.71 \\
\hline 6 & Docosane & & Alkane & $\mathrm{C} 22 \mathrm{H} 46$ & 310 & 1.84 & 22.27 \\
\hline 7 & $\begin{array}{l}\text { 5--tert-Butyl-4-isopropyl 2- } \\
\text { methylphenol }\end{array}$ & & Phenol & $\mathrm{C} 14 \mathrm{H} 22 \mathrm{O}$ & 206 & 0.4 & 22.84 \\
\hline 8 & E-14-Hexadecenal & & & $\mathrm{C} 16 \mathrm{H} 30 \mathrm{O}$ & 238 & 2.11 & 24.53 \\
\hline 9 & 1-octadecanol & $\begin{array}{l}\text { Stearyl } \\
\text { alcohol }\end{array}$ & & $\mathrm{C} 18 \mathrm{H} 38 \mathrm{O}$ & 270 & 1.93 & 28.87 \\
\hline 10 & Lucenin2 & & & $\mathrm{C} 27 \mathrm{H} 30 \mathrm{O} 16$ & 610 & 0.54 & 29.54 \\
\hline 11 & Furoscrobiculin B & & & $\mathrm{C} 15 \mathrm{H} 20 \mathrm{O} 2$ & 232 & 4.31 & 31.50 \\
\hline 12 & $\begin{array}{l}\text { 1,2Benzendicarboxylic acid } \\
\text { dibutyle ester }\end{array}$ & $\begin{array}{l}\text { Dibutyl } \\
\text { phthalat }\end{array}$ & & $\mathrm{C} 16 \mathrm{H} 22 \mathrm{O} 4$ & 278 & 0.73 & 32.38 \\
\hline 13 & $\begin{array}{l}\text {-6-Methyl-2-(3-phenyl-4- } \\
\text { oxothiazolin-2-yliden } \\
\text { e)aminopyridine }\end{array}$ & & & C15H13N3OS & 283 & 1.38 & 33.24 \\
\hline 14 & $\begin{array}{l}\text { 9,12-octadecadionic } \\
\text { acid }(z, z) \text { methylester }\end{array}$ & $\begin{array}{l}\text { Linoleic } \\
\text { acid methyl } \\
\text { ester }\end{array}$ & Fatty acid & $\mathrm{C} 19 \mathrm{H} 34 \mathrm{O} 2$ & 294 & 8.41 & 34.72 \\
\hline 15 & $\begin{array}{l}\text { 9-octadeconic acid } \\
\text { methylester }\end{array}$ & $\begin{array}{l}\text { Methyl } \\
\text { elaidate }\end{array}$ & Fatty acid & $\mathrm{C} 19 \mathrm{H} 36 \mathrm{O} 2$ & 296 & 38.97 & 34.83 \\
\hline 16 & $\begin{array}{l}\text { Phthalicacid,di(2- } \\
\text { propylpentyl)ester }\end{array}$ & & $\begin{array}{l}\text { Plasticizer } \\
\text { compound }\end{array}$ & $\mathrm{C} 24 \mathrm{H} 38 \mathrm{O} 4$ & 390 & 3.53 & 42.24 \\
\hline 17 & Squalene & & & $\mathrm{C} 30 \mathrm{H} 50$ & 410 & 8.40 & 46.22 \\
\hline 18 & $\begin{array}{l}\text { 4H-Cyclopropa } \\
\text { [5',6']benz[1',2':7,8]azuleno[5,6 } \\
\text { b]oxiren-4-one,8acetyloxy)- } \\
\text { 1,1a,1b,1c } \\
\text { 2a,3,3a,6a,6b,7,8,8adodecahy } \\
\text { dro-3a,6b,8a-trih } \\
\text { ydroxy-2a-(hydroxymethyl)- } \\
1,1,5,7-t e t r a m e t h y l\end{array}$ & $\begin{array}{l}\text { Valtrate } \\
\text { fatty acid } \\
\text { ester }\end{array}$ & Fatty acid & $\mathrm{C} 22 \mathrm{H} 30 \mathrm{O} 8$ & 422 & 1.19 & 50.21 \\
\hline 19 & $\begin{array}{l}\text { Methyl-8.4-2--Diacetoxy-3- } \\
\text { bromo-6-methoxy-9,10- } \\
\text { dioxo-9,10-dihydro } \\
\text { anthraquinon-2-lmethyl)-4- } \\
\text { (2-methyl[1,3]dioxolan-2-yl)- } \\
\text { 3-oxobutanoate }\end{array}$ & & & $\mathrm{C} 29 \mathrm{H} 27 \mathrm{BrO} 12$ & 646 & 2.25 & 54.09 \\
\hline
\end{tabular}


Table 2: GC\MS of methanol extract of Chlorella vulgaris

\begin{tabular}{|c|l|c|c|c|c|c|c|}
\hline No & \multicolumn{1}{|c|}{ Name of compound } & $\begin{array}{c}\text { Common } \\
\text { name }\end{array}$ & Group & $\begin{array}{c}\text { Molecular } \\
\text { formula }\end{array}$ & $\begin{array}{c}\text { Molecular } \\
\text { weight }\end{array}$ & $\begin{array}{c}\text { Peak } \\
\text { area\% }\end{array}$ & RT \\
\hline 1 & $\mathbf{1 , 8 - c i n e o l e ~}$ & $\begin{array}{c}\text { Eucalyptus } \\
\text { oil }\end{array}$ & $\begin{array}{c}\text { Mono- } \\
\text { terpenoid }\end{array}$ & C10H18O & 154 & 1.00 & 9.68 \\
\hline 2 & $\begin{array}{l}\text { EXOBORNYL } \\
\text { ACETATE }\end{array}$ & terpenoid & $\mathrm{C} 12 \mathrm{H} 20 \mathrm{O} 2$ & 196 & $\mathbf{2 1 . 6 3}$ & 17.02 \\
\hline 3 & $\begin{array}{l}\text { Phenol,2- methyl } \\
\text {-5,(1-methylethyl) }\end{array}$ & Pinocarvon & phenol & $\mathrm{C} 10 \mathrm{H} 14 \mathrm{O}$ & 150 & 9.83 & 17.34 \\
\hline 4 & trans-Caryophyllene & & terpene & $\mathrm{C} 15 \mathrm{H} 24$ & 204 & 1.12 & 20.47 \\
\hline 5 & $\mathbf{1 - H e p t a d e c e n e}$ & Alkene & $\mathrm{C} 17 \mathrm{H} 34$ & 238 & 1.55 & 24.51 \\
\hline 6 & Heptadecene & Alkene & $\mathrm{C} 17 \mathrm{H} 36$ & 240 & 5.19 & 26.89 \\
\hline 7 & $\begin{array}{l}\text { Hexadecanoicmethyl } \\
\text { ester }\end{array}$ & $\begin{array}{c}\text { Palmitic } \\
\text { acid }\end{array}$ & Ester & $\mathrm{C} 17 \mathrm{H} 34 \mathrm{O} 2$ & 270 & 1.87 & 31.57 \\
\hline 8 & $\begin{array}{l}\text { Octadecadienoic 9,12- } \\
\text { acid (Z,Z)- } \\
\text { methylester }\end{array}$ & $\begin{array}{c}\text { Linoleic } \\
\text { acid methyl } \\
\text { ester }\end{array}$ & Ester & $\mathrm{C} 19 \mathrm{H} 34 \mathrm{O} 2$ & 294 & 6.83 & 34.73 \\
\hline 9 & $\begin{array}{l}\mathbf{- O c t a d e c e n o i c ~ a c i d 9 -} \\
\text { )Z-, methyl ester }\end{array}$ & $\begin{array}{c}\text { Oleic acid } \\
\text { methyl ester }\end{array}$ & Fatty acid & $\mathrm{C} 19 \mathrm{H} 36 \mathrm{O} 2$ & 296 & $\mathbf{2 7 . 8 4}$ & 34.83 \\
\hline 10 & $\begin{array}{l}\text { Benzenedicarboxyl1,2 } \\
\text { ic acid,Bis(2- } \\
\text { ethylhexyl) ester }\end{array}$ & $\begin{array}{c}\text { phthalic } \\
\text { acid ester }\end{array}$ & Fatty acid & $\mathrm{C} 24 \mathrm{H} 38 \mathrm{O} 4$ & 390 & 0.57 & 42.22 \\
\hline 11 & Supreane & lipid & $\mathrm{C} 30 \mathrm{H} 50$ & 410 & 1.04 & 46.21 \\
\hline
\end{tabular}

\section{GCWMS analysis of Microcystis sp.}

From the results of Microcystis extract analysis twelve compounds were determined the highest peak area with high concentration, the highest isTrans-13octadeconicacid, methyle ester with $28.49 \%$, followed by Exobronyle acetate with 14.54\% and Heptadecane,9-octyl with $12.40 \%$ (Table 3).

Michael et al. (2014) illustrated that from different cellular studies; fatty acid derivatives often exhibit activity against cancer cells, but not normal cells. According to this property the use of lipids for new anti-cancer drug development was preferred. 
Table 3: GCIMS of methanol extract of Microcystis sp

\begin{tabular}{|c|c|c|c|c|c|c|c|}
\hline No & Name of compound & $\begin{array}{l}\text { Common } \\
\text { name }\end{array}$ & Group & $\begin{array}{l}\text { Molecular } \\
\text { formula }\end{array}$ & $\begin{array}{c}\text { Molecular } \\
\text { weight }\end{array}$ & $\begin{array}{c}\text { Peak } \\
\text { area\% }\end{array}$ & RT \\
\hline 1 & $\begin{array}{l}\text { Benzene4- } \\
\text { ethyle1,2dimethyl }\end{array}$ & & $\begin{array}{l}\text { Aromatic } \\
\text { alkane }\end{array}$ & $\mathrm{C} 10 \mathrm{H} 14$ & 134 & 1.93 & 9.50 \\
\hline 2 & 1,8-Cineole & & Alchol & $\mathrm{C} 10 \mathrm{H} 18 \mathrm{O}$ & 154 & 1.63 & 9.68 \\
\hline 3 & Exobronyle acetate & & terpenoid & $\mathrm{C} 12 \mathrm{H} 20 \mathrm{O} 2$ & 196 & 14.54 & 17.03 \\
\hline 4 & Docosane & & Alkane & $\mathrm{C} 22 \mathrm{H} 46$ & 310 & 1.45 & 22.26 \\
\hline 5 & Heptadecane,9-octyl & & $\begin{array}{c}\text { Alkane } \\
\text { hydrocarbon }\end{array}$ & $\mathrm{C} 25 \mathrm{H} 52$ & 352 & 12.40 & 26.86 \\
\hline 6 & Flavone & & flavonoid & $\mathrm{C} 27 \mathrm{H} 30 \mathrm{O} 15$ & 594 & 0.35 & 29.81 \\
\hline 7 & $\begin{array}{l}\text { Octadecane,3-ethyl-5- } \\
\text { (2,ethylebutyle) }\end{array}$ & & & C26H54 & 366 & 1.59 & 31.48 \\
\hline 8 & $\begin{array}{l}\text { Hexadeconicacidmethy } \\
\text { le ester }\end{array}$ & $\begin{array}{l}\text { Palmitic } \\
\text { acid methyl } \\
\text { ester }\end{array}$ & Fatty acid & $\mathrm{C} 17 \mathrm{H} 34 \mathrm{O} 2$ & 270 & 1.62 & 31.59 \\
\hline 9 & $\begin{array}{l}\text { Trans-13- } \\
\text { octadeconicacid,methy } \\
\text { le ester }\end{array}$ & $\begin{array}{c}\text { Oleic } \\
\text { acidmethyl } \\
\text { ester }\end{array}$ & Fatty acid & $\mathrm{C} 19 \mathrm{H} 36 \mathrm{O} 2$ & 296 & 28.49 & 34.84 \\
\hline 10 & $\begin{array}{l}\text { 1,2- } \\
\text { Benzendicarboxylicaci } \\
\text { d,bis(ethylehexyl)ester }\end{array}$ & $\begin{array}{l}\text { Phthalic } \\
\text { acid ester }\end{array}$ & Fatty acid & $\mathrm{C} 24 \mathrm{H} 38 \mathrm{O} 4$ & 390 & 4.93 & 42.23 \\
\hline 11 & $\begin{array}{l}2,6,10,14,18,22- \\
\text { Tetraosahexane,2,6,10, } \\
\text { 15,19,23-hexamethyl }\end{array}$ & Squalene & & $\mathrm{C} 30 \mathrm{H} 50$ & 410 & 1.86 & 46.22 \\
\hline 12 & $\begin{array}{l}\text { Pregn-4-ene-3,20- } \\
\text { dione,11 hydroxy- } \\
\text { 17,21-bisTrimethyl } \\
\text { silyl)oxy\}[bis(O- } \\
\text { methyloxime),11 á }\end{array}$ & Steroid & Sterol & $\begin{array}{l}\mathrm{C} 29 \mathrm{H} 52 \mathrm{~N} 2 \\
\mathrm{O} 5 \mathrm{Si} 2\end{array}$ & 564 & 1.32 & 54.08 \\
\hline
\end{tabular}

\section{HPLC analysis of algal extract}

It was obvious from Table 4 that there are four bioactive compound in Gracilaria dendroids; the highest concentration of compounds was cholestrylemyristate with $97 \%$ relative concentration at $8.01 \mathrm{RT}$, and then followed by phytol and Cholest-5-en-3-ol with percentage 50\% and $19 \%$ at (21.85-0.72) RT, respectively. Finally, 2-hydroxy myristic acid appeared with $18 \%$ abundance at 5.72RT.Phytol act as antimicrobial potency and play role in insulin production for human. Sheeja et al. (2016) studied the methanolic extract of the Gracilaria edulis by Gas Chromatography mass spectral fragmentation 
pattern and illustrated that the purified compound is Phytol which was analyzed against MCF-7 using MTT assay method denoting significant anti-proliferation activity and the IC50 of phytol was 125 cell lines.

Table 4: HPLC analysis of Gracilaria dendroids, Chlorella vulgaris and Microcystis sp.

\begin{tabular}{|c|c|c|c|c|}
\hline & Compound name & $\begin{array}{c}\text { Molecular } \\
\text { weight }\end{array}$ & RT & $\begin{array}{c}\text { Relative } \\
\text { concentration \% }\end{array}$ \\
\hline \multirow{4}{*}{ 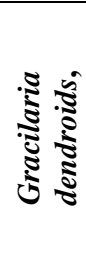 } & Phytol & 296.5 & 21.85 & 50 \\
\hline & Cholesterylmyristate & 597 & 8.01 & 97 \\
\hline & 2-hydroxymyristic acid & 244.37 & 5.72 & 18 \\
\hline & Cholest-5-en-3-ol & 386.7 & 0.72 & 19 \\
\hline \multirow{6}{*}{ 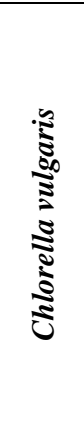 } & Lutein & 568 & 9.84 & 15 \\
\hline & $\alpha$-Tocopherol & 430.71 & 24.55 & 18 \\
\hline & Astaxanthine & 596.84 & 23.77 & 45 \\
\hline & Ascorbic acid & 176.12 & 30.41 & 44 \\
\hline & Zeathanthine & 568 & 22.38 & 8 \\
\hline & CuracinA & 373.6 & 16.27 & 6 \\
\hline \multirow{6}{*}{ 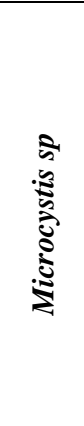 } & Cyanopeptoline & 957 & 15.94 & 29 \\
\hline & Microcystine & 995 & 26.77 & 30 \\
\hline & Aeruginosin & 635 & 0.77 & 6 \\
\hline & Micropeptine & 987 & 12.05 & 75 \\
\hline & Nodularine & 824.9 & 23.96 & 23 \\
\hline & Microgynon & 608 & 27.13 & 25 \\
\hline
\end{tabular}


The fatty acid 2-hydroxy myristic acid is long chain and act as emulsifier and surfactant for industrial also used as energy source .Cholesterol myristate has been used in the composition of lipid nanoparticles as drug carrier systems for drugs with low water solubility. Yosie et al. (2016) isolated different compounds from G. changii, G. manilaensis and Gracilaria sp. and revealed the presence of hexadecanoic acid (palmitic acid) as a major compound and choles-5-en-3-ol from the diethyl ether extracts. Moreover, 2-hydroxymyristic acid and cholesterylmyristate. In Chlorella vulgaris astaxanthine represent $45 \%$ abundance, followed by ascorbic acid with $44 \%$ relative abundance and also found that $\alpha$-tocopherol with $18 \%$.Lutein with $15 \%$ abundance and the minor abundance components were zeathanthine and curacin A with (8-6)\%, respectively. The obtained compounds have biological activity; Lutein acts as an antioxidant, protecting cells against the damaging effects of free radicals. Tocopherols have been suggested to reduce the risk of cancer duo to their strong antioxidant properties. Curacin A has been characterized as potent antiproliferative cytotoxic compound with notable anticancer activity for several cancer lines including renal, colon, and breast cancer (Verdier et al., 1998 and Gu et al., 2007). Ascorbic acid is water soluble vitamin act as antioxidant and free radical scavenger. Astaxanthine is a lipid-soluble pigment has anticancer properties as mentioned by Palozza et al. (2009) which showed that astaxanthine inhibited the growth of fibrosarcoma, breast, and prostate cancer cells and embryonic fibroblasts. The cytotoxic effects of zeaxanthin(lipid soluble antioxidants) on two human uveal melanoma cell lines (SP6.5 and C918) measured by MTT assay which revealed that zeaxanthin reduced the cell viability of melanoma cells (Ming-Chao et al, 2013). Finally as illustrated in Table 4 the highest concentration in Microcystis sp. extract was micropeptine with 75\%abundace, then microcystine with $30 \%$ abundance, followed by cyanopeptoline and microgynon with 29 and $25 \%$ relative abundance respectively. The minor components were nodularine $23 \%$ abundance and aeruginosin $6 \%$. Microcystins are stable hydrophilic cyclic heptapeptides with a potential to cause cellular damage following uptake via organic anion-transporting polypeptides (OATP), developing analogues of microcystin cyanotoxins for efficiently targeting the OATP-expressing metastatic cancers, which are resistant to conventional chemotherapy treatment represent a potential novel targets for anticancer drugs (Sainis et al., 2010).

Egyptian J. of Phycol. Vol. 21, 2020 


\section{Anticancer effect of algal extracts}

The in vitro cytotoxic activity of the methanolic crude extracts of Chlorella vulgaris, Microcystis sp. and Gracilaria dendroides was evaluated against liver cancer cell line (HepG-2), human breast adenocarcinoma cell line (MCF-7) and epithelial colorectal adenocarcinoma cells (CaCO-2). Different concentrations of the tested extracts were used to calculate the values of $\mathrm{IC}_{50}$ (the half-maximal inhibitory concentration). Doxorubicin (DOX) has been used as a positive control. The MTT assay results (Table 5and Fig. 1) showed that crude extract of Gracilaria dendroides had the strongest activity on HepG-2 cell lines with $\mathrm{IC}_{50}$ value $15.46 \mu \mathrm{g} / \mathrm{ml}$. Concerning MCF-7 cell line, the most potent crude extract was the Chlorella vulgaris $\left(\mathrm{IC}_{50}\right.$ value of $15.53 \mu \mathrm{g} / \mathrm{ml}$ ) followed by the Microcystis sp. $\left(\mathrm{IC}_{50}\right.$ value of $\left.23.70 \mu \mathrm{g} / \mathrm{ml}\right)$ and Chlorella vulgaris $\left(\mathrm{IC}_{50}\right.$ value of $76.29 \mu \mathrm{g} / \mathrm{ml}$ ). On the other hand, evaluation the cytotoxic activity for the three algae species extracts against epithelial colorectal adenocarcinoma cells (CaCO-2) showed higher activity for Chlorella vulgaris with $\mathrm{IC}_{50}=14.63 \mu \mathrm{g} / \mathrm{ml}$ followed by extracts of Microcystis sp. $\left(\mathrm{IC}_{50}\right.$ value of $\left.15.86 \mu \mathrm{g} / \mathrm{ml}\right)$ and Gracilaria dendroides $\left(\mathrm{IC}_{50}\right.$ value of $16.50 \mu \mathrm{g} / \mathrm{ml}$ ). Our results on Chlorella vulgaris consistent with Balaji et al. (2017) which showed that the extracts of Chlorella vulgaris induced concentration-dependent cytotoxic effects $(84.11 \%)$ of cell viability in MCF7with $100 \mu \mathrm{g} / \mathrm{ml}$ after an exposure of 48 hours. Prakash et al. (2017) reported that Chlorella vulgaris possessed cytotoxic activity against human breast adenocarcinoma cell line (MCF-7). Certain bioactive compounds such as curacinA detected in Chlorella vulgaris suppress colon and breast cell lines. Several studies have been demonstrated that Chlorella extracts exhibit cytotoxic effects in various human cancer cell lines and has ability to modulate apoptosis signaling pathways. In the hepatoma cell line HepG2, the crude extract of Chlorella vulgaris inhibited cell proliferation and induced apoptosis cascades (Yusof $\boldsymbol{e t}$ al., 2010).

Our results showed that Gracilaria dendroides has cholesterylmyristate (97\%) and cholest-5-en-3-ol (19\%). Kim et al. (2013) illustrated that the cells treated with cholesterol derivatives showed chromatin condensation and DNA fragmentation, which are typical morphologic changes associated with apoptosis. Indeed, cholesterol induced apoptosis in A2058 cell via the mitochondria- 
mediated pathway. Yosie $\boldsymbol{e t}$ al. (2016) showed that the selected edible seaweeds (G. changii, G. manilaensis and Gracilaria sp.) have cytotoxic activity against HL-60 and MCF-7 cell lines and showed good activity as antibacterial and antioxidant agents. So that; the high cholesterol content of Gracilaria dendroides in our results may be the most effective anticancer agents.

Table 5: Cytotoxic activity $\left(\mathrm{IC}_{50}, \mu \mathrm{g} / \mathrm{ml}\right)$ of the methanolic extracts of three algae species against HepG-2, MCF-7 and CaCo-2 cell line.

\begin{tabular}{llll}
\hline \multirow{2}{*}{ Extract } & \multicolumn{2}{l}{ MTT assay $\mathrm{IC}_{\mathbf{5 0}}(\boldsymbol{\mu g} / \mathbf{m l})$} \\
\cline { 2 - 4 } & HepG-2 & MCF-7 & CaCo-2 \\
\hline Chlorella vulgaris & 42.45 & 15.53 & 14.63 \\
Microcystis sp. & 28.40 & 23.70 & 15.86 \\
Gracilaria dendroides & 15.46 & 76.29 & 16.50 \\
Doxorubicin & 1.28 & 0.32 & 0.33 \\
\hline
\end{tabular}

\section{Conclusion}

The evaluation of cytotoxic activity for the three algae species methanolic extracts against epithelial colorectal adenocarcinoma cells $\left(\mathrm{CaCO}_{-2}\right)$ showed higher activity for Chlorella vulgaris with $\mathrm{IC}_{50}=14.63 \mu \mathrm{g} / \mathrm{ml}$. Accordingly, we can say that Chlorella had the strongest activity on MCF-7 and (CaCO-2) cell lines while HepG-2 cell lines most affected by Gracilaria.

\section{Acknowledgment}

The authors would like to express their thanks for the support of production of biofuels from algae and plants project (Implemented and funded by Helwan Univ. A18252). 
A
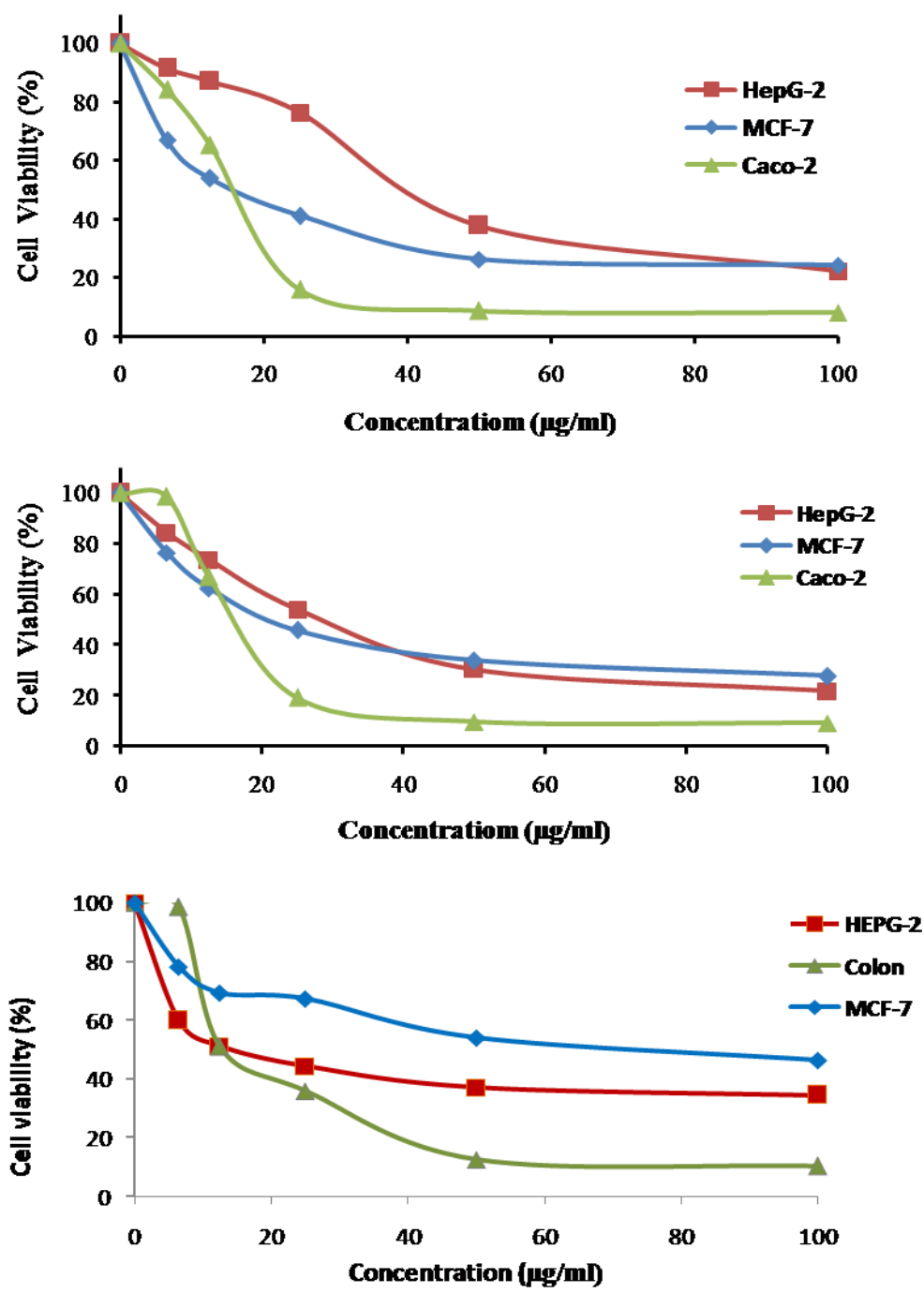

Fig.1: Cytotoxic activity of the methanolic extracts of A: Chlorella vulgaris, B:Microcystis sp. and C: Gracilaria dendroides against HepG-2, MCF-7 and CaCo-2 cell lines 


\section{References}

Ahmed, W.A., El-Semary, N.A., Abd El-Hameed, O. M., El Tawill, G. and Ibrahim, D.M. (2017). Bioactivity and Cytotoxic Effect of Cyanobacterial Toxin Against Hepatocellular Carcinoma. J. Cancer Sci Ther., 9:505-511.

Aleem, A. A. (1993). Marine algae of Alexandria, Egypt.EEAA publication,154.

Apryshko, G.N., Ivanov, V.N., Milchakova, N.A. and Nekhoroshev, M.V. (2005). Mediterranean and Black Sea organisms and algae from mariculture as sources of antitumor drugs. J.Exp.Oncol.,27(2): 94-95.

Balaji, M., Thamilvanan, D., Chidambara, S .V. and Balakumar, B. S. (2017). Anticancer, antioxidant activity and GC-MS analysis of selected micro algal members of chlorophyceae. Int. J. Pharm. Sci. Res., 13: 33023314.

Élica, A. C. G., Teresinha, G. da Silva, Jaciana S. A., Lurdiana, D. de Barros, Laura, M. P. and Antonio, E.G.S. (2013).Cytotoxic activity of marine algae against cancerous cells. Revista Brasil. Farmaco., 23 :668-673

Gheda, S., El-Sheekh, M., Abou-Zeid A. (2018). In vitro anticancer activity of polysaccharide extracted from red alga Jania rubens against breast and colon cancer cell lines. Asian Pac J Trop Med., 11: 583-589.

Gu, L., Geders, T. W., Wang, B., Gerwick, W. H., Håkansson, K., Smith, J. L. and Sherman, D. H. (2007). "GNAT-Like Strategy for Polyketide Chain Initiation". Science. 318: 970-974.

Itoh, H., Noda, H., Amano, H., Zhuaug, C., Mizuno, T. and Ito, H. (1993). Antitumor activity and immunological properties of marine algal polysaccharides, especially fucoidan, prepared from Sargassum thunbergii of Phaeophyceae. Anticancer Res., 13(6A): 2045-52.

Kehr J. C., Picchi, D. G. and Dittmann, E. (2011). Natural product biosynthesis in cyanobacteria: a treasure trove of unique enzymes. Beilstein J .Org Chem.,7:1622-35.Kim, A.D., Lee, Y., Kang, S.H., Kim, G.Y., Kim, H.S. and Hyun, J.W. (2013). Cytotoxic effect of clerosterol isolated 
from Codium fragile on A2058 human melanoma cells.J. Mar. Drugs., 11:418-430.

Manilal, A., Sujith, S., Kiran, G.S., Selvin, J., Shakir, C., Gandhimathi, R. and Panikkar, M.V.N. (2009).Bio-potentials of seaweeds collected from Southwest coast of India. J. Mar. Sci. Technol., 17:67-73.

Matsubara, K., Xue, C., Zhao, X., Mori, M., Sugawara, T. and Hirata, T. (2005). Effects of middle molecular weight fucoidans on in vitro and ex vivo angiogenesis of endothelial cells. Int. J Mol Med.,15(4): 6959.

Michael, M., Herryawan, R., Eziwar, D., Sarah, E. and Tristan, R. (2014). Lipid analogues as potential drugs for the regulation of mitochondrial cell death.Br. J. Pharmacol., 171:2051-2066.

Ming-Chao, B., Richard, R., Ren-Yuan, Z., Steven, A. , Cormick, Mc., Song, E. and Dan-Ning, Hu. (2013). Zeaxanthin Induces Apoptosis in Human Uveal Melanoma Cells through Bcl-2 Family Proteins and Intrinsic Apoptosis Pathway. Evid Based Complement Alternat Med., 2050-82

Mohd, S.M.Z., Roshani, O., Nurhasyimah, R., Mohamad, H. M., Sharida, M.D. and Ahmed, H.Y. (2012). Screening of anticancer activities of crude extracts of unicellular green algae (Chlorella vulgaris) and filamentous blue green algae (Spirulina platensis) on selected cancer cell lines. J. Acad. Univ. Tekn. MARA Negeri Sembilan., 2:38-42.

Ordog, V., Stirk, W.A., Lenobel, R., Bancirova, M, Strand, M. and Van, S. J. (2004).Screening microalgae for some potentially useful agricultural and pharmaceutical secondary metabolites. J .appl. phycol., 16:309-314.

Palozza, P., Torelli, C., Boninsegna, A., Simone, R., Catalano, A., Mele, M.C. and Picci, N. (2009). Growth-inhibitory effects of the astaxanthin-rich alga Haematococcus pluvialis in human colon cancer cells. Cancer Lett., 283:108-117.

Prakash, B., Ashokkumar, L., Virgin, N. M., Miller, S. S., Kavitha, R. and Jegadeeshkumar, D. (2017).Evaluation of anticancer activity of chlorella vulgaris Against human breast adenocarcinoma cell line (MCF7) .Int. J. Adv. Interdisciplinary Res.,4 : 1-3. 
Prescott, G.W. (1982). Algae of the western Great Lakes area, with an illustrated key to the genera of desmids and freshwater diatoms. Otto Koeltz Science Publishers.

Rippka, R., Deruelles, J., Waterbury, J.B., Herdman, M. and Stanier, R.Y. (1979). Generic assignments, strain histories and properties of pure cultures of cyanobacteria. Microbiology., 111(1): 1-61.

Sheeja L, D. Lakshmi, S. B. and Parveen, K. S. (2016). Anticancer activity of phytol purified from Gracilaria edulis against human breast cancer cell line (MCF-7). Int J Curr Sci, 19(4): 36-46.

Van de Loosdrecht, A.A., Ossenkoppele, G.J., Beelen, R.H., Broekhoven, M.G., van Hooff, M.H., Dräger, A.M., Huijgens, P.C. and Langenhuijsen, M.M. (1994). Maturation-dependent susceptibility to monocyte-mediated cytotoxicity in acute myeloid leukemia. Leukemia., (8):1392-400.

Venkataraghavan, R., Jayashree, P. and Thiruchelvi, R. (2019).Gas Chromatography-mass spectrometry analysis of methanol extracts from marine red seaweed Gracilariacorticata. Pharmaco. J. ,11(3): 547-554.

Verdier, P. P., Lai, J.Y., Yoo, H.D., Jurong, M.B., Nagle, D. G., Nambu, M., White, J. D., Falck, J. R., Gerwick, W. H., Day, B. W. and Hamel, E. (1998). Structure-Activity Analysis of the Interaction of Curacin A, the Potent Colchicine Site Antimitotic Agent, with Tubulin and Effects of Analogs on the Growth of MCF-7 Breast Cancer Cells. Molec. Pharm., 53 (1): 62-76.

Xu, H., Yao, L., Sung, H. and Wu, L. (2009): Chemical composition and antitumor activity of different polysaccharides from the roots Actinidiaeriantha. Carb. Polym.,78:316-322.

Yosie, A., Desy, F.S., Tee, C. Y., Faizah, S. H., Gan, M. H., Siti, A. A., Christine, A. O., Abdul, M. A., Jalifah, L., Hiroe, K. and Habsah, M. (2016). Biological Activities of Isolated Compounds from Three Edible Malaysian Red Seaweeds, Gracilaria changii, G. manilaensis and Gracilaria sp. Natural Product Communications.,11 (8): 1117-1120 
Yusof, Y.A., Saad, S.M., Makpol, S., Shamaan, N.A. and Ngah, W.Z. (2010).Hot water extract of Chlorella vulgaris induced DNA damage and apoptosis. Clinics, 65:1371-1377.

Zhang, Z.D., Liang, K., Li, K., Wang, G.Q., Zhang, K.W., Cai, L., Zhai, S.T. and Chou, K.C. (2017). Chlorella vulgaris Induces Apoptosis of Human Non-Small Cell Lung Carcinoma (NSCLC) Cells. Med. Chem., 13: 560568.

\section{المكونات النشطة بيولوجيا من مستخلصات ثلاثة أنواع من الطحالب ونثاطها المضاد للسرطان ضد خطوط الخلايا السرطانية البشرية أنواع دالية}

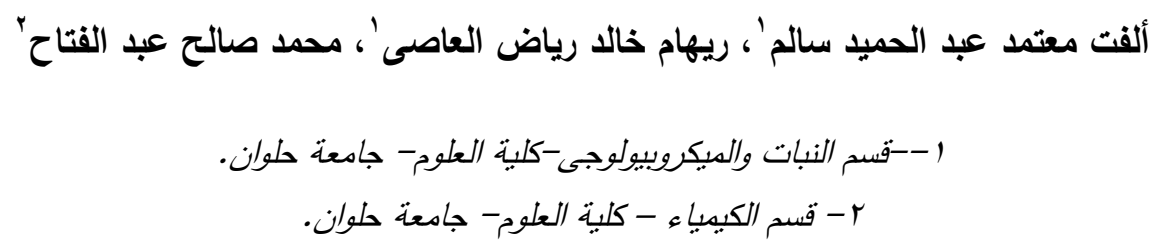

تم إجراء هذه الدراسة للتعرف على المكونات النشطة بيولوجيا للطحلب الأحمر Gracilaria

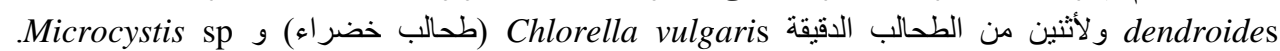

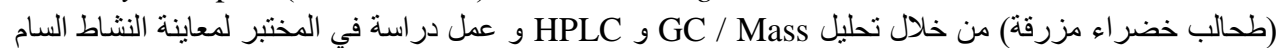

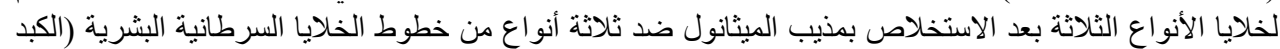

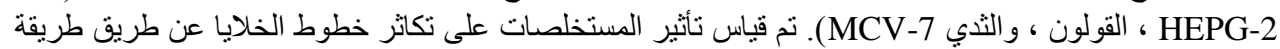

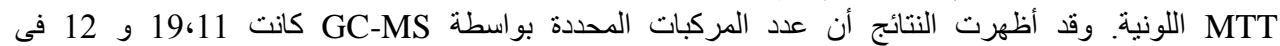

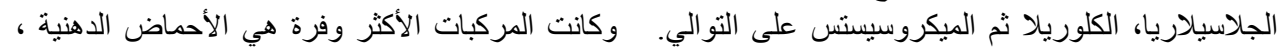

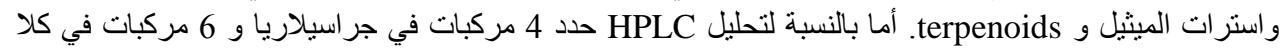

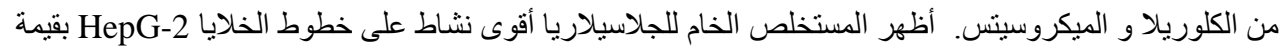

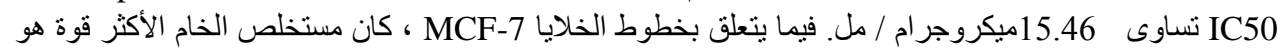

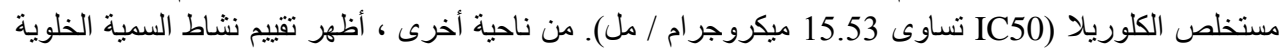

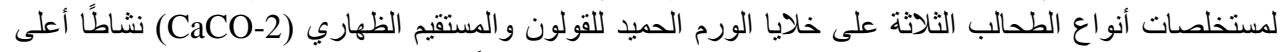

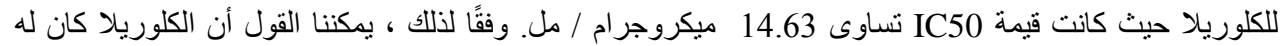

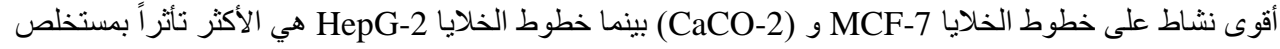

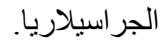

